\title{
The economics of migration:
}

\section{Labour market impacts and migration policies}

Francesco Fasani (Queen Mary University London, CEPR, CReAM and IZA), Joan Llull (MOVE, Universitat Autònoma de Barcelona, and Barcelona GSE), Cristina Tealdi (Heriot-Watt University Edinburgh and IZA) ${ }^{1}$

\begin{abstract}
This article introduces the Special Issue on "The Economics of Migration: Labour Market Impacts and Migration Policies". In the paper, we summarize the selection of articles published in the Special Issue and place their contributions in the context of the main developments in this field. We have organized the articles into three broad thematic areas. The first set of papers provides novel evidence on migrant selection. The following group of articles delves in the core literature of labour market impacts of immigration, with a particular focus on high-skilled immigration and selective immigration policies. A final group of papers deals with more specific - and often controversial - topics: refugee migration, undocumented migration and the political consequences of migration flows. In the concluding remarks, we extract from the different papers some guidance for future migration policies.
\end{abstract}

1 We would like to thank Margo Romans for her great editorial assistance and Helena Skyt Nielsen and Arthur Van Soest for their guidance on the editorial process. Joan Llull acknowledges financial support from the European Research Council (ERC) through Starting Grant n. 804989, from the Generalitat de Catalunya, through SGR Grant 2017-SGR-1765, and from the Spanish Ministery Science and Innovation through grant PGC2018094364-B-I00 and through the Severo Ochoa Programme for Centres of Excellence in R\&D (CEX2019-000915-S). Cristina Tealdi acknowledges financial support from the European Commission through the Marie Curie grant $n$. 322305 and from the Royal Economic Society through the Special Project Grant Scheme. 


\section{Introduction}

The total number of international migrants in the world reached 272 million in 2019 (3.4\% of the global population), an increase of 51 million since 2010. About half of the migrants reside in just 10 countries, and one third of them come from only 10 countries of origin. The United States alone hosts almost 19\% percent of the total migrant population (almost 51 million individuals in 2019), and the MexicoU.S. corridor - with nearly 12 million Mexican migrants residing in the U.S. - is the largest one in the world. The number of immigrants residing in Europe is about 82 million, approximately $30 \%$ of the world migrant population, with the majority of them (about 50 million) living in the EU14+UK area (see United Nations, 2019). While declining fertility in Mexico and other Latin American countries, together with a relative improvement in their political and economic situation, is expected to gradually ease the migratory pressure towards the United States, the opposite is true for European countries, which are closely exposed to countries in Africa and the Middle East that still display high levels of both fertility and instability (Hanson and McIntosh, 2016).

These expected upward trends in international migration clash with widespread hostility towards further increases of the immigrant population in major receiving countries (Pew Research Centre, 2018). Not only citizens in host societies systematically exaggerate the share of foreign-born individuals among the total resident population, but they also systematically underestimate migrants' educational levels and socio-economic integration, while amplifying their cultural and religious differences (Alesina, Miano, and Stancheva, 2019). These biased perceptions suggests that providing more accurate information may possibly reduce hostility towards migrants (Grigorieff, Roth, and Ubfal, 2020). These tensions are at the very core of present migration policy-making.

Receiving countries typically aim at regulating migrant flows through their migration policies. They intend to control both the size of the immigrant inflow and its characteristics, trying to select the best talents as well as catering to the needs of their labour markets. In recent years, an increasing number of countries (such as Canada, Australia, the U.S., and the U.K.) have implemented selective policies. These policies seek to encourage immigration of specific workers, mostly highly qualified, to cover the 
high demand of specialists in certain occupations which is driven by skill-biased technological change. The outcome of these selective policies - and their overall effectiveness in screening migrantscrucially depends on their design and on their interplay with the spontaneous selection of individuals into migration from origin countries.

Migration flows are also driven by supply shifts. Phenomena like refugee migration and undocumented migration emphasize that migration movements can happen despite the efforts of destination countries to influence them through their migration policies. Between 2015 and 2016, for instance, Europe experienced a "refugee crisis", with hundreds of thousands of refugees from Syria, Afghanistan, Iraq, and other countries, reaching European countries to seek humanitarian protection from political persecution, war, and violence. As a result, a number of European countries have experienced yearly increases of their immigrant shares in the range of one percentage point. The ongoing refugee crisis in Venezuela, with over 5.2 million Venezuelan citizens having fled to neighbouring countries, has further contributed to the increase of the global population of forcibly displaced people, which reached a record number of 79.5 million in 2019. Undocumented migration is also a sizeable phenomenon, with the most recent estimates pointing at 4-5 million undocumented immigrants living in Europe (12-16\% of the total Extra-EU immigrant population) and 10.5 million in the U.S. (23\% of the foreign born population) (Pew Research Centre, 2019a,b). Overall, the sizeable increases in economic and refugee migrants over the past decade seem to have generated a rise in xenophobic movements and nationalism around the world. These movements have been fuelled by aggressive political campaigns - such as those that led to the Brexit referendum in the UK or to the election of Donald Trump to the Presidency of the U.S. - that openly appealed to anti-immigration sentiments.

These facts highlight the importance of having a good understanding of the causes and consequences of international migration, and of the effects of different migration policies. A large literature has analysed many of these issues (see Hanson, 2009; Kerr and Kerr, 2011; Nathan, 2014; Dustmann, Schönberg, and Stuhler, 2016; Peri, 2016; and Blau and Hunt, 2019 for recent surveys). In 
many instances, however, the literature has failed to reach a clear consensus. The contradicting nature of many of the findings in these studies reflects the intrinsic difficulties in implementing rigorous evaluations of migration impact. The main difficulties reside in the aggregate nature of migrant shocks, which prevents a straightforward identification of affected and unaffected individuals, and in the endogenous selection of migrants into countries, regions, sectors, etc., which complicates estimating their causal impact on receiving societies. Economists have tried to overcome these difficulties by implementing a large variety of approaches, ranging from natural experiments and instrumental variables to structural models. While allowing to gain a better understanding of the phenomenon, the heterogeneity in approaches has also raised issues of comparability of alternative findings. The literature on the economics of migration is rich and booming, but it is not settled yet. There are still important advances to be made and this Special Issue illustrates some of them.

The Special Issue includes thirteen articles that tackle some of the most important topics in this literature. They analyse different countries, environments and episodes, using a wide variety of methods and providing novel answers to many policy-relevant questions. The first set of papers provides new evidence on migrant selection. The following group of articles delves in the core literature of labour market impacts of immigration, with a particular focus on high-skilled immigration and selective immigration policies. A final group of papers deals with more specific - and often controversial - topics such as refugee migration, undocumented migration, and the political consequences of migration flows. In this introduction, we first provide a summary of the different articles and of their findings in a unified context (Section 2), and we then highlight what, in our view, are their most important takeaways for migration policy (Section 3).

\section{A guided tour of the special issue}

The first step towards understanding the causes and consequences of international migration is to study who migrates and why. Following the seminal work by Borjas (1987), a large body of literature has focused on migrant self-selection. Many of these articles exploit the variation across countries in 
the returns to skill at origin and at different destination countries to establish whether migrants are positively or negatively selected from the home country populations. These studies often focus on returns to education, or on general returns to unobservable skills. Implicitly, they tend to assume that natives and immigrants skills are perfect substitutes and, hence, they are paid the same price. The first contribution of the Special Issue, by Aparicio-Fenoll and Kuehn (2019) take a different approach, analysing whether individuals take into account the relationship between their skills and those of natives when deciding where to migrate. Whether prospective migrants tend to migrate to countries where their skills are scarce or abundant depends on whether the scarcity of skills in the destination country is driven by a lack of supply or a lack of demand for those skills. In the former case, migrants can benefit from the scarcity and be paid a higher price for those skills, while in the latter case they would face poor labour market conditions. The authors concentrate on English proficiency to empirically test which of the two forces dominates in practice. Exploiting (arguably exogenous) variation in timing of English classes' introduction into compulsory school curricula across European countries, they test whether immigrants who are proficient in English choose to move to countries where many or few individuals speak English. Their estimates show that migrants move to countries where their skills are scarce. This result adds a new interesting dimension to the standard selection model that is worth some additional exploration in future research.

While cross-country studies can provide important insights on migrant selection, they have the disadvantage of limiting the use of rich and detailed micro-datasets, which are typically available for a restricted set of countries. Starting with the seminal work by Chiquiar and Hanson (2005), several authors have analysed the specific case of the Mexico-U.S. corridor (Orrenius, and Zavodny, 2005; Fernández-Huertas Moraga, 2011; Kaestner and Malamud, 2013). Other papers have explored specific setting across the world such as Norway (in the age of mass migration; Abramitzky, Boustan and Eriksson, 2012), Israel (Gould and Moav, 2016), Germany (Parey, Ruhose, Waldinger, and Netz, 2017) or Denmark (Borjas, Kauppinen, and Poutvaara, 2019). In line with these studies, the second article of the Special Issue, Rosso (2019), uses a unique individual-level pre-migration labour market dataset for 
Poland to analyse the nature of self-selection of Polish migrants into two major destination countries: the United Kingdom and Germany. The micro data allows her to analyse selection both in terms of observable (education) and unobservable skills (residual wages). She finds that Polish emigrants to the UK are similarly educated to non-emigrants while being more negatively selected on residual wages. Emigrants to Germany, instead, are disproportionately more likely to fall in the middle of the education distribution but they are no different than non-emigrants in terms of unobservable skills. She suggests that these distinct selection patterns can be rationalized with differences in migration policies. Polish migration to the UK occurred within a free mobility setting, since the British government decided to allow immediate access to the UK labour market to citizens of all New Member States after the 2004 EU Enlargement. On the other hand, migration to the Germany was still heavily regulated, as the German government opted for maintaining in place pre-existing restrictions for a seven-year transitional period.

The importance of migration policies for the self-selection of immigrants has become especially evident in recent years. As we mentioned above, a large number of countries increased the selectivity of their immigration policies, aiming at attracting more skilled workers. These policies often discriminate migrants in terms of education. In the third paper of the Special Issue, Bertoli and Stillman (2020) show that selecting migrants based on education does not necessarily attract the most skilled immigrants. In fact, the authors emphasize that the large importance of unobservable skills for immigrant's productivity does not only dilute the effectiveness of selective policies, but it can also produce perverse effects. Using data for the United States, they compare the distributions of wages for low- and high-educated recent migrants, controlling for other observable characteristics (excluding education). Their results suggest that a policy that selects immigrants based on education does not necessarily perform well in selecting the immigrants that will be the most highly rewarded in the labour market. In fact, when they randomly draw a high- and a low-educated immigrant from the same country of origin in their estimated distributions, they observe the low skilled immigrant to earn more, despite the statistically significant difference in the mean wage of the two groups for most 
origins. Thus, they conclude that an employer-based migration system, such as the one used in Australia (or the H1-B program in the United States) may perform better at selecting high skilled immigrants than a centralized points system based on education. Of course, the effectiveness of such policies depends on the reaction of the local labour market, something that is argued in several papers in this Special Issue, and that we discuss in the next section.

The literature on labour market impact of immigrants is undoubtedly the most developed one in the field of the economics of migration. The most influential research in the last few years have established that relative supplies of immigrants in different skill groups matter in determining their impact on natives' wages and employment (Card, 2001; Borjas, 2003; Card, 2009). This impact also depends on the degree of substitutability between natives and immigrants (Ottaviano and Peri, 2012; Manacorda, Manning, and Wadsworth, 2012), technology adoption (Lewis, 2011), task specialization (Peri and Sparber, 2009), immigrants' occupational downgrading in host country (Dustmann, Frattini, and Preston, 2013), and on labour market and human capital adjustments by natives (Llull, 2018a). While an important part of the recent research has exploited some modelling structure, ranging from production function frameworks (Borjas, 2003; Card, 2009; Ottaviano and Peri, 2012; Manacorda, Manning and Wadsworth, 2012) to a fully specified dynamic equilibrium models (Llull, 2018a), other influential papers have exploited novel natural experiments that led to sharp increases in migration flows (Dustmann, Schönberg, and Stuhler, 2017; Llull, 2018b; Beerli, Ruffner, Siegenthaler, and Peri, 2018; Monràs, 2020) or to their reduction (Clemens, Lewis, and Postel, 2018). This literature has still not found a clear consensus on the sign and magnitude of the labour market effects of immigration.

This Special Issue contributes to this debate with two studies that both rely on policy changes to obtain some exogenous variation in the exposure to migration flows and thus identify causal impacts of immigration on natives' labour market outcomes. The first one, Hoen (2020), exploits heterogeneity in language requirements across occupations to generate differential exposure to migration flows from Eastern Europe to Norway after the European Union enlargements of 2004 and 2007. She finds evidence of detrimental effects on earnings and on employment of natives, with the 
effects being stronger on earnings for young workers and on employment for older workers. She therefore concludes that language policies may improve immigrant's employment opportunities and spread the impacts of immigration across different groups. In the second paper, Edo and Rapoport (2020) investigate the interplay between labour market regulation and labour market effects of immigration, by exploiting variation in the minimum wages across U.S. states. They find that the impact of immigration on the wages and employment of native workers within a given state-skill cell is more negative in states with low minimum wages and for workers with low education and working experience. They conclude that minimum wages are a useful tool to protect more vulnerable natives against the potentially detrimental effect of immigration on their wages. Both papers, therefore, suggest that there is scope for host country policies -other than migration policies- to influence the impact of migration on natives' outcome in the labour market.

The literature on the effects of high skilled immigration on receiving countries is still relatively more incipient and strongly focused on the U.S. case (for a recent review, see Kerr, Kerr, Özden and Parsons, 2016). Some influential studies have used historical events such as the Fall of the Iron Curtain (Borjas and Doran, 2012) and the emigration of Jews escaping from Nazi Germany (Moser, Voena, and Waldinger, 2014) to evaluate the effects of the immigration of scientists on the scientific production of American researchers. In the current economic context, several articles have analysed the impact of high skilled migration on patenting and entrepreneurship (Hunt and Gauthier-Loiselle, 2010; Kerr and Lincoln, 2010; Moser and San, 2020) and the potential displacement effects on native STEM workers (e.g. Bound, Braga, Golden, and Khanna, 2015; Peri, Shih, and Sparber, 2015; Kerr, Kerr, and Lincoln, 2015; Doran, Gelber, and Isen, 2020; Llull, 2020) and native STEM students (Orrenius and Zavodny, 2015). This Special Issue features three articles on high-skilled migrants. Sparber (2019) studies the H-1B program that allows highly-educated foreign-born workers to secure legal employment in the United States. The annual caps on $\mathrm{H}-1 \mathrm{~B}$ issuances vary across employer type and individuals' U.S.-granted educational degree and H-1B work history. These caps are generally binding in the for-profit sector, but not in all years nor in all cases. Exploiting the different cap restrictions in a 
triple-difference analysis, the paper tests whether firms substitute across different sources of highlyeducated foreign-born H-1B labour. The author finds that, while new H1-B immigrants without U.S. advanced degrees became unavailable due to the more restrictive cap, wage offers to new H1-B workers with advanced U.S. degrees rose, consistent with a substitution effect. However, he finds no effects on wages of established H1-B workers, which he interprets can be due to complementarities or policy restrictions on the mobility of established H1-B visa holders. Ma (2020) takes the analysis to a dynamic equilibrium framework that determines wages of computer science and non-computer science STEM workers. Using the structural model, she estimates the importance of occupational switching in understanding the displacement effect of high skilled immigration (which is particularly over-represented in computer science). In her model, individuals adjust to skilled immigration by changing occupations and investing in human capital. Estimating the demand functions for native and immigrant workers, she finds that skilled immigrants and natives are imperfect substitutes in some occupations but are complements in others. Counterfactual exercises indicate that even large inflows of foreign skilled workers would have minor impacts on domestic workers. Gunadi (2019) examines the role of imperfect substitutability between natives and immigrants and the heterogeneity across different workers to discern the potential economic benefits of STEM immigration on the wage structure in the United States. He finds that U.S. and foreign-born STEM workers with similar skills have a high but finite elasticity of substitution, implying that the adverse impact of STEM immigration would be more concentrated among immigrant STEM workers themselves. Further, he shows that the increase in foreign STEM workers in the U.S. led to higher average wage of U.S.-born STEM workers, although with distributional consequences, and to a GDP increase (predominantly driven by positive productivity spill-overs). Overall, the three papers conclude that there is only limited scope for displacement effects as a result of complementarities, native worker adjustments and, potentially, policy restrictions on H1-B visa holders.

If high skilled immigration is often a product of targeted policies aimed at attracting foreignborn talents, at the other side of the spectrum we find cases in which immigration does not occur 
because of immigration policies, but rather despite them. The most prominent example is undocumented migration. To a certain extent, the movements of forced migrants seeking a safe haven in often reluctant destination countries also belong to this category. Unsurprisingly, these are areas of migration policies that draw disproportionate media and political attention. This Special Issue contributes to this debate with two papers on undocumented migrants and two on refugees.

The economic literature on undocumented migration (summarized by Hanson, 2006) has focused on the impact of legal status on labour market outcomes (Cobb-Clark, Shiells, and Lowell, 1995; Kossoudji and Cobb-Clark, 2002; Amuedo-Dorantes, Bansak, and Raphael, 2007; Devillanova, Fasani, and Frattini, 2018) as well as on other areas of migrants' behaviour, such as crime (Mastrobuoni and Pinotti, 2015; Pinotti, 2017) or consumption (Dustmann, Fasani, and Speciale, 2017). Many of these papers use amnesties as exogenous source of variation in migrants' residence status. Another group of papers looks at the impact of border and internal enforcement on migration decisions (Hanson and Spilimbergo, 1999; Gathmann, 2008; Lessem, 2018; Allen, Dobbin and Morten, 2018), residential choices of undocumented immigrants (Bohn, Lofstrom, Raphael, 2014; Bohn and Pugatch, 2015; Hoekstra and Orozco-Aleman, 2017) and their overall welfare and behaviour (AmuedoDorantes, Arenas-Arroyo, and Sevilla, 2018; Kuka, Shenhav, and Shih, 2020). Undocumented migration is the object of analysis of the following two papers in the Special Issue. They both study the case of the United States - a country with an estimated stock of 10.5 million of unauthorized migrants in 2019, approximately $4.6 \%$ of the U.S. labour force (Pew Research Centre, 2019c) - and use demographic characteristics to identify "likely undocumented immigrants" in large surveys. Borjas and Cassidy (2019) study the wage gap between observationally equivalent legal residents and undocumented immigrants in the United States. They find a very large unadjusted gap in the log hourly wage (over 35\%) which almost entirely disappears once the calculation adjusts for differences in observable socioeconomic characteristics. They show that the gap increases over the life cycle of migrants (since the age-earning profiles of undocumented migrants are flat) and with the supply of undocumented immigrants in the local labour market (being larger in states that host a larger unauthorized 
population). The wage gap is also affected by policy changes that affect legal restrictions on the employment of undocumented immigrants: it decreases with the Deferred Action for Childhood Arrivals (DACA) and increases with E-Verify. The impact of changes in enforcement policies on labour market performance of undocumented immigrants is the focus of the paper by Amuedo-Dorantes, Arenas-Arroyo, and Sevilla (2020). These authors assess the impact on undocumented migrants' behaviour and labour supply of changes in the regulations regarding their access to driving licences in the United States. They find that likely undocumented men increase their weekly hours of work in response to the availability of driver's licenses. The effect is moderate, but not negligible. Limiting access to driving licences produce two detrimental effects on labour market prospects of immigrants: it constrains mobility, geographically limiting the set of working opportunities they can have access to, and it reduces the set of occupations they can have, excluding jobs that require driving. Indeed, the authors observe an increase in commuting time and a higher likelihood of having an occupation that requires driving.

The economic literature on forced migration focuses on the labour market performance of refugees vis-à-vis natives and/or non-forced migrants (Cortes, 2004) as well as on the effects of specific aspects of the asylum policy, such as geographic dispersal programs (Edin, Fredriksson and Åslund, 2003; Damm, 2009; Beaman, 2012), generosity of income support for refugees (LoPalo, 2019), asylum application processing times (Hainmueller, Hangartner, and Lawrence, 2016) and employment bans (Fasani, Frattini, and Minale, 2020). For recent reviews of this literature, see Becker and Ferrara (2019) and Brell, Dustmann, and Preston (2020). Notably, several important papers in the labour market impact literature of migration have relied on refugee shocks as a source of identification, starting from the seminal paper by Card (1990) on the Mariel Boatlift and early work by Hunt (1992), Friedberg (2001), and Angrist and Kugler (2003). ${ }^{2}$ The recent spike in refugee flows towards European countries has called for interventions aimed at fostering refugees' integration in host countries and 
for evaluations of best policy practices. Two papers in this Special Issue directly address this demand. Azlor, Damm, and Schultz-Nielsen (2020) study a nation-wide refugee allocation policy in Denmark to assess the effects of local labour market conditions on future economic integration of refugee migrants. Relying on the exogeneity of the allocation of refugees to areas, they find that being placed in areas with stronger labour demand has a persistent positive effect on refugees' employment probability. Their findings suggest caution in implementing dispersal policies of refugees and asylum seekers, since these allocations are often conceived to spread and reduce the costs of hosting refugees rather than to maximize their labour market integration. Battisti, Giesing, and Laurentsyeva (2019) provide timely evidence on refugees' labour market integration in Germany, in the immediate aftermath of the so-called 2015 European refugee crisis. They conducted a field experiment to evaluate the impact of personalised job search assistance on the employment of recently arrived refugees. In the experiment, a randomly selected treatment group received job-matching support by an NGO that identified suitable vacancies and sent the refugees' CVs to potential employers. The authors find no effects six months after the intervention and a moderate positive effects after one year, which is larger in magnitude for low-educated workers. Their findings point at the challenges posed by the labour market integration of recently arrived forced migrants as well as at potential avenues to overcome them.

Despite being relatively rare events and smaller in size in comparison to general immigration, refugee crises and illegal immigration flows typically trigger the strongest emotional reactions (both in favour and against) and, for this reason, they are highly debated in the political arena. The last paper included in this Special Issue, Moriconi, Peri, and Turatti (2019), contributes to the growing literature on the political consequences of immigration (Dustmann, Vasiljeva, and Damm, 2019; Hangartner, Dinas, Marbach, Matakos, and Xefteris, 2019; Tabellini, 2020; Steinmayr, forthcoming) by investigating the impact of immigration on political support for welfare state expansion in Europe. Using national election data for twelve European countries, the authors first analyse the effects of immigration on individual voting behaviour, holding constant the political platform of parties. Then, 
they shift focus from voters to political parties, studying how the political agenda of European parties respond to immigration. Their results point at polarizing effects of migration that depend on the characteristics of migrants themselves. While skilled migrants shift preferences towards enhancing the role of the welfare state, unskilled migrant produce an effect of opposite sign. This paper emphasizes how multifaceted voters' response to the exposure to migrant flows actually is and how migrants' characteristics can influence it in one direction or the other. As pointed out also by other studies in this field, citizens in host countries do not have to be inevitably hostile to immigration. Although strongly negative reactions attract plenty of media and political attention, more pragmatic and positive responses among voters can also prevail, suggesting room for policy-making and migration policies to better mediate the relationship between foreign workers and hosting societies.

\section{What did we learn? A few lessons for migration policy}

As discussed in the previous section, the selection of articles published in this Special Issue touches upon some of the most important aspects of migration for both the academic and policy debates.. These papers propose novel analyses, approaches and viewpoints that contribute to advancing our understanding of this phenomenon, while suggesting potentially effective interventions on migration policies.

There are several conclusions that can be drawn from these studies to inform future policy making in the area of migration. As far as migrant selection is concerned, migrants tend to move to countries where their skills are relatively scarce, filling in gaps in the natives' set of skills (AparicioFenoll and Kuehn, 2019). Migrants' selection on observable and on unobservable characteristics, however, do not necessarily move in the same direction and are responsive to migration regimes in destination countries (Rosso, 2019). Policies that select migrants based on education level (pointbased systems) do not necessarily attract the immigrants with the most sought-after skills and those that will be the most highly rewarded in the host country labour market (Bertoli and Stillman, 2020). In a world in which countries have increasingly more selective immigration policies, policy makers 
should take these results into account, and be aware that their policies may generate unintended consequences. At the same time, they should also take into consideration what the existing evidence suggests on the consequences of high skilled migration for natives and established immigrants. The findings discussed in this SI imply that there is limited scope for displacement effects between highskilled migrants and native workers. More restrictive caps on granting new $\mathrm{H}-1 \mathrm{~B}$ visas do not seem to have produced significantly positive effects on wages of established H1-B workers in the U.S. (Sparber, 2019). When focusing on STEM workers, skilled immigrants and natives appear to be imperfect substitutes in some occupations and complements in others, which implies that even large inflows of foreign skilled workers would have limited negative impacts on domestic workers (Ma, 2020). The increase in foreign STEM workers in the U.S. is estimated to increase average wage for native STEM workers (although with distributional consequences) and GDP, the latter predominantly driven by positive productivity spill-overs (Gunadi, 2019). All these results explain why countries are increasingly more favourable in admitting high skilled immigrants relative to low skilled ones.

The evidence in this SI further suggests that host countries could use labour market policies to influence the impact of low-skilled immigration on native workers' outcomes. For instance, the provision of host-country language policies is an effective way not only to foster migrants' socioeconomic integration of immigrants, but it is also a way to share the burden of potentially detrimental effects of immigration on labour market outcomes among a larger set of native population groups (Hoen, 2020). Further, employment protection legislation in destination countries -such as minimum wages- may also be considered a useful tool to protect more vulnerable native workers against the potentially detrimental effect of immigration on their wages (Edo and Rapoport, 2020).

The papers on undocumented and forced migration included in this Special Issue emphasize the challenges and hurdles in the labour market integration of these two specific types of migrants. If the current conditional wage gap between documented and undocumented migrants in the U.S. seems to be smaller than previously estimated, the flat age-earning profiles of the latter group leads to a widening gap over the life cycle of migrants (Borjas and Cassidy, 2019). Among the many obstacles 
unauthorized workers face in hosting countries -and that can contribute to the observed lower employment and earnings associated to the lack of legal status- restrictions to the access to driving licenses may negatively affect labour supply, reducing the set of working opportunities migrants face (Amuedo-Dorantes, Arenas-Arroyo, and Sevilla, 2020). These two papers suggest that lifting restrictions on undocumented migrants may reduce their wage and employment gaps, respectively. Refugee migrants face similar difficulties, lagging behind with respect to comparable economic migrants. Adequate policy interventions, however, can help bridging these gaps. Their labour market outcomes can be improved, for instance, by being placed upon arrival in areas with stronger labour demand (Azlor, Damm, and Schultz-Nielsen, 2020) or by receiving tailored job search assistance (Battisti, Giesing, and Laurentsyeva, 2019).

Finally, we learn from Moriconi, Peri, and Turatti (2019) that migrants' characteristics -and their skills, in particular- are pivotal in shaping host country citizens' preferences and voting behaviour. This is arguably the most daunting step for migration policy nowadays: not only policymakers need to be able to design effective and sensible policies in the area of migration, but they also need to convince voters to support and vote for them. The negative cycle of poorly designed policies, leading to negative outcomes and generating further hostility against immigrants seems to work well to favour politicians and parties that thrive on anti-immigrant sentiments. Establishing cycles of opposite sign, in which policies succeed in making the most out of migration for both migrants and natives is still very much work-in-progress. It is our job as economists to contribute to this process by providing rigorous analyses of the causes and consequences of international migration, discarding biased views based on emotion, and suggesting policies that improve the welfare of individuals in both sending and receiving societies. We believe this Special Issue is an important step in this direction.

\section{References}

Abramitzky R, Boustan LP, Eriksson K. Europe's Tired, Poor, Huddled Masses: Self-Selection and Economic Outcomes in the Age of Mass Migration. American Economic Review 2012;102; 1832-1856. 
Alesina A, Armando M, Strancheva S. Immigration and Redistribution. NBER Working Papers 24733; 2019.

Allen T, Dobbin C, Morten M. Border Walls. NBER Working Papers 25267; 2018.

Amuedo-Dorantes C, Arenas-Arroyo E, Sevilla A. Immigration enforcement and economic resources of children with likely unauthorized parents. Journal of Public Economics 2018;158; 63-78.

Amuedo-Dorantes C, Arenas-Arroyo E, Sevilla A. Labor market impacts of states issuing of driver's licenses to undocumented immigrants. Labour Economics 2020;63; 101805.

Amuedo-Dorantes C, Bansak C, Raphael S. Gender Differences in the Labor Market: Impact of IRCA. American Economic Review 2007;97; 412-416.

Angrist JD, Kugler A. Protective or counter-productive? Labour market institutions and the effect of immigration on EU natives. Economic Journal 2003;113; F302-F331.

Aparicio Fenoll A, Kuehn Z. Immigrants move where their skills are scarce: Evidence from English proficiency. Labour Economics 2019;61; 101748.

Azlor L, Damm AP, Schultz-Nielsen ML. Local labour demand and immigrant employment. Labour Economics 2020;63; 101808.

Battisti M, Giesing Y, Laurentsyeva N. Can job search assistance improve the labour market integration of refugees? Evidence from a field experiment. Labour Economics 2019;61; 101745.

Beaman LA. Social networks and the dynamics of labour market outcomes: evidence from refugees resettled in the U.S. Review of Economic Studies 2012;79; 128-161.

Becker SO, Ferrara A. Consequences of forced migration: A survey of recent findings. Labour Economics 2019;59; 1-16.

Beerli A, Ruffner J, Siegenthaler M, Peri G. The Abolition of Immigration Restrictions and the Performance of Firms and Workers: Evidence from Switzerland. NBER Working Papers 25302; 2018.

Bertoli S, Stillman S. All that glitters is not gold: Wages and education for US immigrants. Labour Economics 2019; 61; 101749. 
Blau FD, Hunt J. The economic and fiscal consequences of immigration: highlights from the National Academies Report. Business Economics 2019;54; 173-176.

Bohn S, Lofstrom M, Raphael S. Did the 2007 Legal Arizona Workers Act Reduce the State's Unauthorized Immigrant Population. Review of Economics and Statistics 2014;96; 258-269.

Bohn S, Pugatch T. U.S. Border Enforcement and Mexican Immigrant Location Choice. Demography $2015 ; 52 ; 1543-1570$.

Borjas GJ. Self-Selection and the Earnings of Immigrants. American Economic Review 1987;77; 531553.

Borjas GJ. The Labor Demand Curve Is Downward Sloping: Reexamining the Impact of Immigration on the Labor Market. Quarterly Journal of Economics 2003;118; 1335-1374.

Borjas GJ, Cassidy H. The wage penalty to undocumented immigration. Labour Economics 2019;61; 101757.

Borjas GJ, Doran KB. The Collapse of the Soviet Union and the Productivity of American Mathematicians. Quarterly Journal of Economics 2012;127; 1143-1203.

Borjas GJ, Kauppinen I, Poutvaara P. Self-selection of Emigrants: Theory and Evidence on Stochastic Dominance in Observable and Unobservable Characteristics. Economic Journal 2019;129; 143-171.

Borjas GJ, Monràs J. The labour market consequences of refugee supply shocks. Economic Policy 2017;32; 361-413.

Bound J, Braga B, Golden JM, Khanna G. Recruitment of Foreigners in the Market for Computer Scientists in the United States. Journal of Labor Economics 2015;33; 187-223.

Brell C, Dustmann C, Preston I. The Labor Market Integration of Refugee Migrants in High-Income Countries. Journal of Economic Perspectives 2020;34; 94-121.

Card D. The Impact of the Mariel Boatlift on the Miami Labor Market. ILR Review1990;43; 245-257.

Card D. Immigrant Inflows, Native Outflows, and the Local Labor Market Impacts of Higher Immigration. Journal of Labor Economics 2001;19; 22-64. 
Card D. Immigration and Inequality. American Economic Review 2009;99; 1-21.

Chiquiar D, Hanson GH. International Migration, Self-Selection, and the Distribution of Wages: Evidence from Mexico and the United States. Journal of Political Economy 2005;113; 239-281.

Clemens MA, Hunt J. The Labor Market Effects of Refugee Waves: Reconciling Conflicting Results. ILR Review 2019;72; 818-857.

Clemens MA, Lewis EG, Postel HM. Immigration Restrictions as Active Labor Market Policy: Evidence from the Mexican Bracero Exclusion. American Economic Review 2018;108; 1468-1487.

Cobb-Clark DA, Shiells CR, Lowell BL. Immigration Reform: The Effects of Employer Sanctions and Legalization on Wages. Journal of Labor Economics 1995;13; 472-498.

Cortes KE. Are refugees different from economic immigrants? Some empirical evidence on the heterogeneity of immigrant groups in the United States. Review of Economics and Statistics 2004;86; 465-480.

Damm AP. Ethnic enclaves and immigrant labor market outcomes: quasi-experimental evidence. Journal of Labor Economics 2009;27; 281-314.

Devillanova C, Francesco F, Frattini T. Employment of Undocumented Immigrants and the Prospect of Legal Status: Evidence from an Amnesty Program. ILR Review 2018;71; 853-881.

Doran KB, Gelber A, Isen A. The Effects of High-Skilled Immigration Policy on Firms: Evidence from Visa Lotteries. NBER Working Papers 20668; 2020.

Dustmann C, Fasani F, Speciale B. Illegal Migration and Consumption Behaviour of Immigrant Households. Journal of the European Economic Association 2017;15; 654-691.

Dustmann C, Frattini T, Preston I. The Effect of Immigration along the Distribution of Wages. Review of Economic Studies 2013;80; 145-173.

Dustmann C, Schönberg U, Stuhler J. The Impact of Immigration: Why Do Studies Reach Such Different Results? Journal of Economic Perspectives 2016;30; 31-56.

Dustmann C, Schönberg U, Stuhler J. Labor Supply Shocks, Native Wages, and the Adjustment of Local Employment. Quarterly Journal of Economics 2017;132; 435-483. 
Dustmann C, Vasiljeva K, Damm AP. Refugee Migration and Electoral Outcomes. Review of Economic Studies 2019; 86; 2035-2091.

Edin P-A, Fredriksson P, Åslund O. Ethnic Enclaves and the Economic Success of Immigrants-Evidence from a Natural Experiment. Quarterly Journal of Economics 2003;118; 329-357.

Edo A, Rapoport H. Minimum wages and the labour market effects of immigration. Labour Economics $2019 ; 61 ; 101753$.

Fasani F, Frattini T, Minale L. Lift the Ban? Initial Employment Restrictions and Refugee Labour Market Outcomes. CReAM Discussion Paper Series 2010; 2020.

Fernández-Huertas Moraga J. New Evidence on Emigrant Selection. Review of Economics and Statistics 2011;93; 72-96.

Friedberg RM. The Impact of Mass Migration on the Israeli Labor Market. Quarterly Journal of Economics 2001;116; 1373-1408.

Gathmann C. Effects of enforcement on illegal markets: Evidence from migrant smuggling along the Southwestern border. Journal of Public Economics 2008;92; 1926-1941.

Gould ED, Moav O. Does High Inequality Attract High Skilled Immigrants? Economic Journal 2016;126 1055-1091.

Grigorieff A, Roth C, Ubfal D. Does Information Change Attitudes Toward Immigrants? Demography 2020;57; 1117-1143.

Gunadi C. An inquiry on the impact of highly-skilled STEM immigration on the U.S. economy. Labour Economics 2019;61; 101751.

Hainmueller J, Hangartner D, Lawrence D. When lives are put on hold: lengthy asylum processes decrease employment among refugees. Science Advances 2016;2; 1-7.

Hangartner D, Dinas E, Marbach M, Matakos K, Xefteris D. Does exposure to the refugee crisis make natives more hostile? American Political Science Review 2019;113; 442-455.

Hanson, GH. Illegal Migration from Mexico to the United States. Journal of Economic Literature 2006;44; 869-924. 
Hanson GH. The Economic Consequences of the International Migration of Labor. Annual Review of Economics 2009;1; 179-208.

Hanson GH, McIntosh C. Is the Mediterranean the New Rio Grande? US and EU Immigration Pressures in the Long Run. Journal of Economic Perspectives 2016;30; 57-82.

Hanson GH, Spilimbergo A. Illegal Immigration, Border Enforcement, and Relative Wages: Evidence from Apprehensions at the U.S.-Mexico Border. American Economic Review 1999;89; 1337-1357.

Hoekstra M, Orozco-Aleman S. Illegal Immigration, State Law, and Deterrence. American Economic Journal: Economic Policy 2017;9; 228-252.

Hoen MF. Immigration and the Tower of Babel: Using language barriers to identify individual labour market effects of immigration. Labour Economics 2020;65; 101834.

Hunt J. The Impact of the 1962 Repatriates from Algeria on the French Labor Market. ILR Review 1992;45; 556-572.

Hunt J, Gauthier-Loiselle M. How Much Does Immigration Boost Innovation? American Economic Journal: Macroeconomics 2010;2; 31-56.

Kaestner R, Malamud O. Self-selection and international migration: New evidence from Mexico. Review of Economics and Statistics 2013;96; 78-91.

Kerr SP, Kerr WR, Özden Ç, Parsons C. Global Talent Flows. Journal of Economic Perspectives 2016;30; 83-106.

Kerr SP, Kerr WR. Economic Impacts of Immigration: A Survey. Finnish Economic Papers; 2011; 24; 132.

Kerr SP, Kerr WR, Lincoln WF. Skilled Immigration and the Employment Structures of US Firms. Journal of Labor Economics 2015;33; 147-186.

Kerr WR, Lincoln WF. The Supply Side of Innovation: H-1B Visa Reforms and U.S. Ethnic Invention. Journal of Labor Economics 2010;28; 473-508.

Kossoudji SA, Cobb-Clark DA. Coming out of the Shadows: Learning about Legal Status and Wages from the Legalized Population. Journal of Labor Economics 2002;20; 598-628. 
Kuka E, Shenhav N, Shih K. Do Human Capital Decisions Respond to the Returns to Education? Evidence from DACA. American Economic Journal: Economic Policy 2020;12; 293-324.

Lessem RH. Mexico-U.S. Immigration: Effects of Wages and Border Enforcement. Review of Economic Studies 2018:85; 2353-2388.

Lewis EG. Immigration, Skill Mix, and Capital Skill Complementarity. Quarterly Journal of Economics 2011;126; 1029-1069.

Llull J. Immigration, Wages, and Education: A Labour Market Equilibrium Structural Model. Review of Economic Studies 2018a;85; 1852-1896.

Llull J. The Effect of Immigration on Wages: Exploiting Exogenous Variation at the National Level. Journal of Human Resources 2018b;53; 608-622.

Llull J. Selective Immigration Policies and the U.S. Labor Market. Mimeo Universitat Autònoma de Barcelona. 2020.

LoPalo M. The effects of cash assistance on refugee outcomes. Journal of Public Economics 2019;170; 27-52.

Ma J. High skilled immigration and the market for skilled labour: The role of occupational choice. Labour Economics 2020;63; 101791.

Manacorda M, Manning M, Wadsworth J. The Impact Of Immigration On The Structure Of Wages: Theory And Evidence From Britain. Journal of the European Economic Association 2012;10; 120-151.

Mastrobuoni G, Pinotti P. Legal Status and the Criminal Activity of Immigrants. American Economic Journal: Applied Economics 2015;7; 175-206.

Monràs J. Immigration and Wage Dynamics: Evidence from the Mexican Peso Crisis. Journal of Political Economy 2020; 128; 3017-3089.

Moriconi S, Peri G, Turati R. Immigration and voting for redistribution: Evidence from European elections. Labour Economics 2019;61; 101765.

Moser P, Voena A, Waldinger F. German Jewish Emigres and US Invention. American Economic Review 2014;104; 3222-3255. 
Moser P, San S. Immigration, Science, and Invention. Evidence from the Quota Acts. Mimeo New York University; 2020.

Nathan M. The wider economic impacts of high-skilled migrants: a survey of the literature for receiving countries. IZA Journal of Migration 2014;3.

Orrenius PM, Zavodny M. Self-selection among undocumented immigrants from Mexico. Journal of Development Economics 2005;78; 215-240.

Orrenius PM, Zavodny M. Does Immigration Affect Whether US Natives Major in Science and Engineering? Journal of Labor Economics 2015;33; 79-108.

Ottaviano GIP, Peri G. Rethinking the Effect of Immigration on Wages. Journal of the European Economic Association 2012;10; 152-197.

Parey M, Ruhose J, Waldinger F, Netz N. The Selection of High-Skilled Emigrants. Review of Economics and Statistics 2017;99; 776-792.

Peri G. Immigrants Productivity and Labor Markets. Journal of Economic Perspectives 2016;30; 1-30.

Peri G, Shih K, Sparber C. STEM Workers, H-1B Visas, and Productivity in US Cities. Journal of Labor Economics 2015;33; 225-255.

Peri G, Sparber C. Task Specialization, Immigration, and Wages. American Economic Journal: Applied Economics 2009;1; 135-169.

Pew Research Centre. Many worldwide oppose more migration - both into and out of their countries. 2018.

Pew Research Centre. Europe's unauthorized immigrant population peaks in 2016, then levels off. 2019a.

Pew Research Centre. Mexicans decline to less than half the U.S. unauthorized immigrant population for the first time. 2019b.

Pew Research Centre. 5 facts about illegal immigration in the U.S. 2019c. 
Pinotti P. Clicking on Heaven's Door: The Effect of Immigrant Legalization on Crime. American Economic Review 2017;107; 138-168.

Rosso A. Emigrant selection and wages: The case of Poland, Labour Economics 2019;60; 148-175.

Sparber C. Substitution between groups of highly-educated, foreign-born, H-1B workers. Labour Economics 2019;61; 101756.

Steinmayr A. Contact versus Exposure: Refugee Presence and Voting for the Far-Right, Review of Economics and Statistics, forthcoming.

Tabellini M. Gifts of the Immigrants, Woes of the Natives: Lessons from the Age of Mass Migration, Review of Economic Studies 2020;87; 454-486.

United Nations, 2019. International Migrant Stock 2019. Population Division, Department of Economic And Social Affairs, United Nations. Database: POP/DB/MIG/Stock/Rev.2019. 